\title{
THE ACADEMIC Copyright In THE Age OF CoMmodification of SCIENTIFIC RESEARCH
}

*Università degli Studi di Trento - Trento, Italy

\begin{abstract}
There is a large stream of literature related to academic copyright. Nonetheless, a comprehensive interdisciplinary analysis of the interplay between economic rights and moral right of paternity appears to be missing. Furthermore, the impact of commodification of research on academic copyright has not been sufficiently investigated. The basic thesis of this article is that academic copyright with reference to academic texts is currently going through a distortion that alters its nature and functions. This distortion is one of the effects of commodification of scientific research. This paper dwells on these aspects with a focus on the role of modern science and the context in which research is performed and highlights the perverse effects of the current evaluation system based on metrics and numbers and the scientific publishing system dominated by an oligopoly of information and analytics providers. Open Science can represent a tool to defend independence of science and academic freedom, though strong actions are required to change the current situation.
\end{abstract}

Keywords

Academic copyright, Intellectual Property, Evaluation of Science, Open Science

\section{Academic copyright: social norms, law, technology, evaluation ${ }^{1}$}

In this article "academic copyright" is intended as a system of limited exclusive control of scientific publications (articles, books, etc.) based on the interplay of different factors: social norms (ethos of science), formal legal norms (copyright law), technology (movable type printing, digital technologies) and lastly, metrics (evaluation measures).

In the legal literature, the topic of copyright of scientific publications has been explored several times. However, there is a lack of an in-depth interdisciplinary inquiry into the relationship between two aspects of academic law: authorship and economic rights. Moreover, the impact of commercialization of scientific research on academic copyright has not been sufficiently

\footnotetext{
1 This text is a rewriting based on an essay published in $\mathrm{F}$. Di Ciommo, O. Troiano (editors), Giurisprudenza $e$ autorità indipendenti nell 'epoca del diritto liquido. Studi in onore di Roberto Pardolesi, La Tribuna, Piacenza, 2018, pp. 769-780, the text was republished with some modifications in $\mathrm{R}$. Caso, La rivoluzione incompiuta. La scienza aperta tra diritto d'autore e proprità intellettuale, Ledizioni, Milano, 2020, pp. 127-14, and in V. Falce
}

investigated.

This article aims to begin to fill, at least partially, the above mentioned gaps. In other words, the purpose of this paper is to reconstruct a puzzle whose pieces are scattered in reflections pertaining to different scientific disciplines.

The basic thesis is that academic copyright with reference to academic texts is currently going through a distortion that alters its nature and functions. This distortion is one of the effects of the commodification of scientific research.

Two aspects of the institutional organization of contemporary science are the result of a pernicious alliance between the scientific community and the market: anonymous peer reviewing and use of metrics - in particular, the measurement of citations of scientific works - for evaluation purposes.

The anonymity of peer reviewing along with

(editor), Fairness e innovazione nel mercato unico digitale, Giappichelli, Torino, 2020; it is also available as working paper in Trento LawTech Research Paper series no.36, University of Trento, Trento, 2018: http://hdl.handle.net/11572/210960. The author is grateful to Paola Gargiulo for the English translation of the orginal text. 
the measurement of citations managed by commercial intermediaries represent a real poison that is seriously making science ill. The evaluation system is linked to a considerable strengthening of the private control of information carried out through intellectual property laws, contracts and technologies.

The underlying premise is that the Internet should, in theory, be a powerful tool for transforming, strengthening and improving scientific dialogue. Internet is a means of communication with its own characteristics noticeably different from orality, writing, movable type, radio and television. If Internet is conceived and built as a tool for improving communication, science should also benefit.

In the field of academic copyright, if in the past the exclusive control of scientific writings, limited by the ample room granted to public domain, has proved useful to the progress of modern science based on the assertion of the public nature of dialogue at the expense of secrecy, more than ever today, in the age of the Internet we should bear witness to the definitive affirmation of the values of publicity (making publicly available), sharing and transparency in scientific works.

However, the reality molded in recent decades tells a different story.

Although Internet was born in academia in accordance with the principles of openness of science, its evolution (or involution) has seen the rise of powerful commercial entities that dominate the scene.

One of the most important issues is the concentration of market and information power in the hands of giant platforms such as Google and Facebook. The same can be said of scientific publishing.

The digitalization of scientific publishing has exacerbated the market concentration triggered by evaluation systems focused on anonymous peer reviewing and bibliometrics. This market is now occupied by commercial agglomerates such as Elsevier, which manages not only the destiny of publishing in the strict sense, but also bibliometric evaluation and, through the latter, the governance of science.

In the field of scientific communication, the commodification of publications is to be related to an event dating back in time: the entrepreneurship in university and scientific research.

This dynamics is driven by several elements. They include, for the purpose of reasoning, the emphasis on individual contribution to the detriment of value generated by the scientific community as a whole, the emphasis on competition to the detriment of cooperation, and the extension of intellectual property and its corresponding restriction of public domain.

The commodification of scientific research associated with the strengthening of exclusive control of intellectual property alters the balance between defending individual interests and recognizing the collective dimension of scientific progress and poses serious risks to academic freedom and the progress of science (Lametti, 2011).

The distortion of academic copyright occurs with respect to two main aspects: the right of paternity and economic rights. The former is no longer the engine of a public dialogue on science but the gear of an evaluation system that leads to flattening of thought, self-referentiality and violation of research integrity, the latter are no longer incentives for investments aimed at disseminating scientific works but levers of monopoly power.

The Open Science movement, whose forerunner is identified with the emergence of free software and whose first formalization, the Budapest Open Access Initiative dates back to 2001, has tried to react, on the ethical front of formal rules and technologies, to the corruption of academic copyright.

When the regulatory and technological infrastructure of Open Access was set up, it envisaged that not for profit academic and scientific institutions could play a leading role in building Open Science.

Today, we must ask ourselves whether scientific and academic institutions have the strength and the will to represent an independent voice from the market.

In other words, we can ask ourselves whether Open Science can represent a tool to defend independence of science and academic freedom, or whether it is bound to constitute just another cog in the market mechanism and in particular, in the platform capitalism that dominate the Internet.

\section{Academic copyright as tool for a public science}

Modern science is a synonym for public science. The openness of knowledge contrasts with secrecy practices previously in use. In 1610 Galileo published the Sidereus Nuncius. In 1655 the 
Royal Society published the number 0 of Philosophical Transactions.

Scientists are a small élite protected by powerful patrons. The first modern copyright law had yet to see the light of day (Izzo, 2010)2. Print publishing is just one step of a knowledge-building process that is inevitably becoming open.

The presentation and discussion of experiments as well as the texts describing them are a public and community events that take place within the first scientific academies (Johns, 2009).

It is primarily the interplay between social norms and communication technology that manages the dynamic relationship between the individual and the community.

The social norms of science urge to register, through publication of a printed text, the priority of discovery (Merton, 1957). The name of an author associated with a scientific text in print becomes a seal of priority.

In particular, scientific journals are registers of priority (Guédon, 2001). The same informal rules of science limit the function of authorship to a recognition of the individual contribution by peers (Rossi, 2007).

The progress of science remains a collective enterprise. Print can also give the illusion of completeness of a work and encourage claims of (intellectual) property on a text (Ong, 1986), but the development and transmission of knowledge remain the result of a diffuse and interconnected intelligence through many word technologies (orality, writing, print).

The very transmission of knowledge from one generation of scientists to another is entrusted not only to codified knowledge but also to its tacit dimension (Polanyi, 1962).

In other words, science remains a process of community and scattered construction of knowledge that unfolds in different forms of communication.

The printed text is important because it establishes a link between the author's name and the words that describe the theory, allowing - also thanks to piracy (Johns, 2009) - the rapid dissemination of ideas and information, but tells only part of a much richer and complex process.

Formal copyright, made up of laws and judicial decisions, intersects with science when the

2 On the events leading to the approval of Statute of Anne of 1710, see in Italian U. Izzo, Alle origini del copyright e del diritto d'autore. Tecnologia, interessi e cambiamento giuridico, Carocci, Roma, 2010, pp. 69 ff., spec. pp. 109 ff. informal rules of the latter have already laid the institutional foundations governing the dynamic relationship between the individual and the community.

However, the interplay between copyright and the rules of science remains fraught with friction.

Copyright law was born as a form of liberation from patronage assigning the author economic fortunes to the market. Scientific authors, on the other hand, must rely on new forms of patronage such as a salary from a university or a research center. Scientific authors are, in fact, much more interested in peer recognition - which their academic-scientific career depends on - than in their success in bookstores.

It is no coincidence that scientists transfer economic rights (copyright) to publishers without claiming compensation. ${ }^{3}$

It is worth paying attention to some critical issues highlighted in the literature on the subject (Biagioli, 2013; Bently \& Biron, 2014).

a) Copyright law focuses on the mode of expression of intellectual work (the scientific text). Ideas, facts and data - according to the traditional distinction between protected form and unprotected idea - remain in public domain. Norms of science, on the other hand, focus their attention on the content of a theory.

It is not so much the text that describes a theory, but the very theory that becomes the object of a claim of priority.

A claim of priority whose function consists in a legitimate expectation of being recognised by peers, gives credit to an individual contribution, but does not advance any claim of exclusivity on a use of the theory itself.

b) The copyright law in conferring ownership on intellectual work adopts general criteria and in particular, the one attributing ownership of a work to its creator. There may also be additional criteria such as the nature of institution an author is affiliated to or the type of employment relationship (self-employed or employed) that binds a scientist to an institution.

The social norms of science, on the other hand, attribute ownership of a text according to the practices of each scientific community, and in any

\footnotetext{
3 Obviuosly the practice in the field of textbooks and popular science books is different.
} 
case push forward the autonomy of an author from his/her own institution.

A scientist delivers speeches and writes in the name of science and not of the institution he/she is (temporarily) affiliated to.

The ownership of a scientific publication always belongs to its author and never to the institution he/she is affiliated to.

In determining the criteria to resolve the conflicting viewpoints or in any case to reduce the friction between informal rules and copyright, it is necessary to keep in mind what are the functions of academic copyright.

In terms of priority of discovery and authorship of a text, the goal is to defend freedom of thought and, at the same time, to attribute responsibility in case of violations of scientific integrity such as plagiarism. In terms of economic rights, the goal is to guarantee the widest dissemination to scientific publications, which in the era of printing press determines the need to find agreements with commercial publishers.

In other words, academic copyright is one of the pillars of the institutional structure that supports the public and (more or less) democratic nature of science.

From this perspective, it is not possible to fully understand academic copyright without exploring the existing relationship between the political order of society and the institutional structure of science.

To this end, it is worth mentioning two authors, already cited in the notes: Robert K. Merton and Michael Polanyi.

In 1942, in the age of the rise of totalitarian regimes, Merton wrote a fundamental essay on science in the democratic order. He developed the theory of social norms of scientists: communism, universalism, disinterest, originality and organized scepticism (Merton, 1942). Science thrives in democracy and reflects its founding values.

A scientist publishes his discoveries and in doing so he shares his ideas, reserving for himself only the right to be recognized as the author of a contribution. The emphasis on originality and priority that fuels competition and disputes is balanced by modesty and awareness that science is essentially a collective, cooperative and cumulative enterprise.

A publication authored by one or more scientists is a lever, at the same time, of individual contributions and communal work which leads to a cross-check (organized skepticism) by peers.

Twenty years later, when the increased state funding was also matched by the claim to orient science to social goals, Polanyi claimed full autonomy from political power for scientists.

The republic of science appears as a system to generate a coordination of independent initiatives and to aim to an indefinite purpose.

Self-coordination entails publishing scientific papers, where each researcher takes note of peer publications and reacts by publishing in turn.

No single scientist is individually responsible for the advancement of science, which is instead a result of a multitude of contributions scattered throughout different fields of research specialization (Polanyi, 1962).

Beyond the ideological differences inspiring their opinions, the two authors - Merton and Polanyi - share the idea that science progresses when it dialogues publicly and independently of political power.

However, they wrote at a time when scientific research was undergoing its great transformation on its way to become big science. If on the one hand, the role of the state and public funding was growing, on the other, science was becoming more and more business oriented by mimicking the market logics (Johns, 2009; Greco \& Silvestrini, 2009).

In democratic societies, as long as public funding remains the main source of finance and scientists are ensured job stability and the effective scientific autonomy is guaranteed, through the application of constitutional principles, then academic copyright can exercise its functions of freedom, responsibility and dissemination of ideas.

Starting from the 1980s, the political context and the public funding strategies have changed in Western countries, a new risk jeopardizes the autonomy of science and academic copyright: market domination. Moreover, the worst form of market, which concentrates power in the hands of few enterprises.

\section{The distortion of academic copyright in the age of commodification and metrics}

What happens if scientific publications gradually lose importance and data becomes the new wealth on which the appetites of information market giants are concentrated? 
What happens if informal norms of science become more and more formalized and their role appears increasingly marginalized by a logic that attributes a power of objectivity to numbers and metrics?

Current academic copyright is a result of interaction among several factors: informal rules, formal copyright laws, technology and metrics (for example, metrics that purport to measure the impact of science).

It is a sick interaction that seriously threatens the progress of science. It produces centralization of decision-making power, uniformity with dominant thought and a propensity to fraud. I will briefly review each factor starting with metrics.

\section{A) Metrics.}

In the world of big science there are more scientists from more countries, and the number of publications is growing exponentially, but the time a scientist can individually dedicate to reading a single publication decreases.

The idea of selecting a finite number of journals and measuring citations received by each article and each journal in a short time span, emerged from this scenario.

In other words, archives have been created to measure the citational impact in a short term. The citation archive model was developed in the 1960s, in a non-globalized world based on the use of paper, by a scientist who became an entrepreneur - Eugene Garfield (Garfield, 1955) and founded the archetype of a business bound to flourish in the digital age.

Although the initial purpose of impact measurement of journals, and subsequently of authors, was to be a tool in bibliographical research, it quickly turned into indicators used to assess academic careers of individuals and performance of academic bodies such as universities and departments (Pascuzzi, 2017). 4

This is one of the many poisoned fruits generated by applying business-oriented approach to the world of science.

The evaluation of "products" - nowdays designating scientific publications - is done by

\footnotetext{
${ }^{4}$ On use of indicators in Italy, see G. Pascuzzi, Il fascino discreto degli indicatori: quale impatto sull'università? Foro it., 2017, I, p. 2549.

5 On university rankings, see C. O'Neil, Armi di distruzione matematica. Come i big data aumentano la disuguaglianza e minacciano la democrazia, /Weapons of Math Destruction: How Big Data Increases Inequality and Threatens Democracy,
}

using metrics and numbers. The metrics and numbers are used to evaluate through rating and ranking (O’Neil, 2017) $)^{5}$, assuming their impartiality as a replacement of human bias.

The discursive assessment expressed through words is replaced by algorithms and formulas based on numbers (Supiot, 2015) ${ }^{6}$. The evaluation power is concentrated in the hands of those who know and build algorithms, formulas and metrics.

In a highly competitive environment where a greatly globalized science offers universitiesenterprises a number of precarious young researchers, the typical feedback of scientists is to try to exploit the automatism of metrics (Biagioli, 2016).

The aim is no longer a search for truth - or less courtly: accumulation of knowledge - but a climb in ranking. In this unprecedented universe of evaluation, new forms of violation of ethics and scientific integrity arise, such as, for example, plagiarism aimed not so much at "stealing" successful scientific ideas as, more trivially, at increasing the number of publications to list in one's own curriculum vitae (Biagioli, 2012).

In addition to a physiological growth in number of publications due to a greater number of scientists, we observe a pathological multiplication of publications as a response to metrics.

Universities are prone to large commercial information providers like Elsevier that centralize both editorial and evaluation power.

The most paradoxical aspect of this evaluation power is its blatant contradiction with the spirit of public science.

In fact, the data on which metrics are built are normally secret. On the other hand, scientific journals, which current commercial databases have built their fortune on, could not become so well established without a solid alliance with some scientists (editors, referees, members of scientific committees, etc.). (Guédon, 2001).

An alliance that relies on a recent practice, on anonymous peer reviewing represents another form of betrayal of public character of modern science (Israel, 2017).

Penguin Random House LLC., New York, Giunti Editore S.p.A./Bompiani, Firenze-Milano, 2017, pp. $75 \mathrm{ff}$.

${ }^{6}$ The replacement of words with numbers in the field of research evaluation is only a sign of a momentous change, see A. Supiot, La gouvernance par les nombres (Cours au Collège de France 2013-2014), Fayard, Paris, 2015. 
It goes without saying the anonymity of peer reviewing exposes the publishing process to various forms of ethos of science violations such as revenge among academic schools and plagiarism of other people's research.

The most grotesque aspect of the story is the presumed objectivity of numbers used to make short-term decisions - such the assignment of public funding to universities - which, by definition, have nothing to do with the tentative acknowledgement of progress of science which is a long-term activity by its nature.

Multi-author scientific papers (up to thousand authors) - as it occurs in some disciplinary fields are less and less expression of a public use of reason (Kant, 1784), and more and more a pure generator of citations.

B) Informal norms of science.

In the era of entrepreneurialized, commercialized and hyperorganized science, the rules of ethos appear less and less informal and more and more formalized.

An example is the attribution of authorship of a scientific text.

Previously practices of scientific communities established who was entitled to be named as author in a paper. Now there is a plethora of documents from scientific societies, university associations and individual institutions regulating academic authorship, in black and white, and in great detail.

The same applies to the battle against violations of scientific integrity. Also, in this area a group of experts is emerging, such as the members of ethics committees, who professionally are responsible for fighting violation of scientific ethos.

Academic plagiarism is regulated by definitions, procedures and use of anti-plagiarism software. This is another aspect of academic copyright distortion.

In the past, academic copyright was an expression of the informal norms of an - at least potentially open - community. Presently it is a result of norms which are expression of institutions which tend to be closed and hyperorganized: universities, scientific societies, associations of institutions etc.

C) Copyright law

Traditionally, copyright law protects a work of authorship. Although the definition of a work of authorship has always been controversial, it is beyond dispute that a work is a much more complex object than data, whatever definition we want to give to the latter.

Today the trend of copyright laws and part of its case law application is to protect data (or information).

Although the principle of idea-expression dichotomy is still formally in force and potentially can play the role of the last bastion of free circulation of ideas, it is undeniable the current trend to extend exclusivity to what was previously in the public domain.

The European provisions in the field of copyright (the sui generis right in the context of databases, the legal protection of technological protection measures, and the recent EU directive $790 / 2019$ on copyright in the digital single market) represent pieces of a legislative framework based on the policies of a legislator prone to commercial interests.

The impact of this legislation and its interaction with contracts (proprietary licenses) and technological protection measures on science functioning have long been overlooked.

For decades literature has focused much more on patents than on copyright. Just recently it was understood the devastating impact of this legislative trend on public science and, therefore, on the very essence of modern science (Reichman \& Okediji, 2012; David, 2004).

D) Technology.

For a long time, it was thought the Internet could be a tool for enhancing communication. In scientific fields, the web was a possible candidate, due to its ability to combine different characteristics of speech technologies (orality, writing, printing press), to strengthen the public and democratic character of science (Harnad, 1991).

Instead, the Internet has evolved towards a concentration of information control and power in the hands of large commercial platforms (up to now mostly based in the US, more recently and in the near future also in China). (Berners Lee, 2010).

In science, consolidation of power to control information is particularly evident. Search engines, social networks and information analytics databases dominate the field.

The interaction of the four factors briefly described above leads to a distortion of academic copyright. 
The authorship right of a scientific paper is no longer the engine of a public dialogue and of a dynamic relationship between individual contribution and collective advancement of knowledge, rather a gear of citation metrics with its effects: flattening of thought, self-referentiality and a rise in research integrity breaches (Pievatolo, 2018).

Economic rights are no longer a driving force behind the dissemination of scientific publication, but a means to consolidate power to control information and data. In short, the republic of science is transformed into an empire that moves an army of clones at will. 


\section{REFERENCES}

Bently, L., \& Biron, L (2014). Discontinuities between legal conceptions of authorship and social practices. What, if anything, is to be done?. In M. van Eechoud (Ed.), The Work of Authorship (pp. 237-239). Amsterdam: Amsterdam University Press.

Berners Lee, T. (2010). Long Live the Web: A Call for Continued Open Standards and Neutrality. Scientific American, 303(6), 80-85.

Biagioli, M. (2012). Recycling Texts or Stealing Time?: Plagiarism, Authorship, and Credit in Science. International Journal of Cultural Property, 19, 453-476. Retrieved from https://ssrn.com/abstract=2427955

Biagioli, M. (2013). Rights or Rewards? Changing Frameworks of Scientific Authorship. In M. Biagioli, P. Galison (Eds), Scientific Authorship. Credit and Intellectual Property in Science (pp 253). London-New York: Routledge Taylor \& Francis Group.

Biagioli, M. (2016). Watch out for cheats in citation game. Nature, 535(7611), 201. DOI:10.1038/535201a

David, P. A. (2004). Can "Open Science" be Protected from the Evolving Regime of IPR Protections? Journal of Institutional and Theoretical Economics (JITE) / Zeitschrift für die gesamte Staatswissenschaft, 160(1), 9-34. 21st International Seminar on the New Institutional Economics - The Generation and Distribution of Knowledge.

Di Donato, F. (2009). La scienza e la rete - L'uso pubblico della ragione nell'età del Web. Firenze: Firenze University Press. Retrieved from http://www.fupress.com/archivio/pdf/3867.pdf

Fecher, B., \& Friesike, S. (2014). Open Science: One Term, Five Schools of Thought. In S. Bartling, S. Friesike (Eds.), Opening Science. The Evolving Guide on How the Internet is Changing Research, Collaboration and Scholarly Publishing. (pp. 17-47). New York-London: Springer. Retrieved from https://link.springer.com/content/pdf/10.1007\%2F978-3-319-00026-8 2.pdf

Fitzpatrick, K. (2011). Planned Obsolescence: Publishing, Technology, and the Future of the Academy. New York: University Press.

Garfield, E. (1955). Citation Indexes for Science: A New Dimension in Documentation through Association of Ideas. Science, 122(3159), 108. DOI: 10.1126/science.122.3159.108

Greco, P., \& Silvestrini, V. (2009). La risorsa infinita. Per una società democratica della conoscenza. Roma: Editori Riuniti-University Press.

Guédon, J. C. (2001, 2004). La lunga ombra di Oldenburg: i bibliotecari, i ricercatori, gli editori e il controllo dell'editoria scientifica. Traduzione italiana di M. C. Pievatolo, B. Casalini, F. Di Donato, dall'originale In Oldenburg's Long Shadow: Librarians, Research Scientists, Publishers, and the Control of Scientific Publishing. Association of Research Libraries, 2001, https://www.arl.org/wp-content/uploads/2001/12/inoldenburgs-long-shadow.pdf. Bollettino telematico di filosofia politica. Retrieved from http://bfp.sp.unipi.it/rete/oldenburg.htm

Guédon, J. C. (2015). Toward the Internet of the Mind. Rettrieved from https://www.budapestopenaccessinitiative.org/boai15/Untitleddocument.docx/at_download/file

Harnad, S. (1991). Post-Gutenberg Galaxy: The Fourth Revolution in the Means of Production of Knowledge. Retrieved from http://cogprints.org/1580/ 
Israel, G. (2017). Chi sono i nemici della scienza? Riflessione su un disastro educativo e culturale e documenti di malascienza. Vignate: Lindau

Izzo, U. (2010). Alle origini del copyright e del diritto d'autore. Tecnologia, interessi e cambiamento giuridico. Roma: Carocci.

Johns, A. (2009, 2011). Pirateria - Storia della proprietà intellettuale da Gutenberg a Google. Italian translation by M. Togliani e G. Maugeri from Piracy. The Intellectual Property Wars from Gutenberg to Google, Chicago and London, 2009. Torino: Bollati Boringhieri, 2011.

Kant, I. (1784). Risposta alla domanda: che cos'è l'illuminismo? Traduzione italiana di F. Di Donato, supervisione di M. C. Pievatolo, dall'originale Beantwortung der Frage: Was ist Aufklärung? Berlinische Monatsschrift, 04 (Dezember), 481-494. Bollettino Telematico di Filosofia Politica. Retrieved from http://btfp.sp.unipi.it/dida/kant_7/ar01s04.xhtml\#a037

Lametti, D. (2011). On Creativity, Copying and Intellectual Property. In R. Caso (Ed.), Plagio e creatività: un dialogo tra diritto e altri saperi (pp. 171-182). Trento: Università degli Studi di Trento.

Merton, R. K. (1942). Science and Technology in a Democratic Order. Journal of Legal and Politcal Sociology, 1 (942), 115.

Merton, R. K. (1957). Priorities in Scientific Discovery: A Chapter in the Sociology of Science. American Sociological Review, 22(6), 635.

Merton, R. K. (2000). Teoria e struttura sociale. Voll. I-III: Teoria sociologica; Studi sulla struttura sociale e culturale; Sociologia della conoscenza e sociologia della scienza. Bologna: Il Mulino.

Ong, W. J. (1986). Oralità e scrittura. Le tecnologie della parola. Traduzioine italiana di A. Calanchi dall'originale Orality and Literacy: The Technologizing of the Word. London: Methuen. Bologna: Il Mulino.

O'Neil, C. (2017). Armi di distruzione matematica. Come i big data aumentano la disuguaglianza e minacciano la democrazia. Traduzione italiana dall'originale Weapons of Math Destruction: How Big Data Increases Inequality and Threatens Democracy. New York: Penguin Random House LLC. Milano: Bompiani.

Pascuzzi, G. (2017). Il fascino discreto degli indicatori: quale impatto sull'Università? Il Foro italiano, I, 2549-2554.

Pievatolo, M.C. (2012). L'accademia dei morti viventi, parte prima: la revisione paritaria. Bollettino Telematico di Filosofia Politica, 20 gennaio 2012. Retrieved from https://core.ac.uk/download/pdf/32978042.pdf

Pievatolo, M.C. (2018). Integrità della ricerca: i numeri, gli uomini e la scienza. Bollettino telematico di filosofia politica, 11 maggio 2018. Retrieved from Roars https://www.roars.it/online/integrita-dellaricerca-i-numeri-gli-uomini-e-la-scienza/

Polanyi, M. (1962). The Republic of Science: Its Political and Economic Theory. Minerva, I(1), 54-73. Retrieved from

http://faculty.fgcu.edu/bhobbs/Polanyi\%201962\%20The\%20Republic\%20of\%20Science.pdf

Reichman, J. C., \& Okediji, R. (2012). When Copyright Law and Science Collide: Empowering Digitally Integrated Research Methods on a Global Scale. Minnesota Law Review, 96(4), 1362-1480. Minnesota Legal Studies Research Paper, 12-54. Retrieved from https://papers.ssrn.com/sol3/papers.cfm?abstract id=2149218

Rossi, P. (2007). La nascita della scienza moderna in Europa. Roma-Bari: Laterza. 
Russo, L. (2008). La cultura componibile. Dalla frammentazione alla disgregazione del sapere. Napoli: Liguori editore.

Suber, P. (2012). Open Access. Cambridge (Mass.): MIT Press.

Supiot, A. (2015). La gouvernance par les nombres (Cours au Collège de France 2013-2014). Paris: Fayard.

Swartz, A. (2006). Legacy. Retrieved from http://www.aaronsw.com/weblog/legacy

Swartz, A. (2008). Guerrilla Open Access Manifesto. Eremo, Italy. Retrieved from https://archive.org/stream/GuerillaOpenAccessManifesto/G oamjuly2008_djvu.txt

Weber, M. $(1919,1966)$. La scienza come professione. In Il lavoro intellettuale come professione: Due saggi, traduzione italiana di A. Giolitti dall'originale Politik als Beruf. Berlin: Wissenschaft als Beruf, 1919. Torino: Giulio Einaudi editore, 1966. Retrieved from https://giovineitalia.altervista.org/wpcontent/uploads/2018/05/Max-Weber-Scienza-e-Politica-Come-Professione.pdf

Willinsky, J. (2006). The Access Principle. The Case for Open Access to Research and Scholarship. Cambridge (MA): The Mit Press. Retrieved from http://wiki.lib.sun.ac.za/images/0/03/The-access-principle.pdf 